\title{
Operation of Islamic Religion Education Learning at Tanjungpura Pontianak University Province of West Kalimantan
}

\author{
Lisa'diyah Ma'rifataini ${ }^{1}$, Supriyadi ${ }^{2}$, Munawiroh $^{3}$, Suprapto ${ }^{4}$, Achmad Habibullah $^{5}$ \\ \{lisa.litbang@gmail.com ${ }^{1}$, supriyadi@gmail.com², mun.asrori@gmail.com ${ }^{3}$, \\ supraptolitbang@gmail.com ${ }^{4}$,achmadhabi92@gmail.com $\left.{ }^{5}\right\}$ \\ The Center of Religius Education R\&D Ministry of Religios Affair ${ }^{1,3,4,5}$ \\ STKIP of Panca Sakti ${ }^{2}$
}

\begin{abstract}
Islamic Religious Education (PAI) in General Universities (PTU) has not yet introduced the rationality side of religious teachings. This study aims to determine the implementation of PAI at the University of Tanjung Pura Kalbar. This research is qualitative. PAI research results in the category are sufficient, theoretical, and have not been able to change overall academic behavior. Factors affecting the allocation of learning time are minimal, PAI is oriented to non-practical material and the lack of improvement in PAI lecturer insight PAI core course with a weight of 3 SKS. In 2014 the recruitment of PAI lecturers was conducted in each study program. PAI lecturers already have certifications and receive teaching training so that they can apply the andragogy learning model to their students.
\end{abstract}

Keywords: Learning, Islamic religious education, PTU

\section{Introduction}

The National Education System (No. 20, 2003, chapter V, Art 12) expressly states the right of every student to receive religious education. Every student has the right to get religious education by their religion and taught by educators of the same religion. This means that every student at all levels and levels of education, whether elementary, secondary or high, has the right to get religious education according to the religion they profess and be taught by teachers/lecturers of the same religion.

Religious education referred to in the Act [7], is an education that provides knowledge and shapes the attitudes, personalities, and skills of students in practicing their religious teachings which are carried out at least through subjects/lectures on all lines, levels and type of education. This means that religious education is a compulsory subject at the tertiary level.

The position of the Religious Education course at PTU is included in the Core Curriculum of Higher Education in the Personality Development Courses (MPK) group; along with PPKn and Indonesian. The Higher Education Curriculum (Law No. 12 of 2012) must contain subjects: religion; Pancasila; citizenship; and Indonesian. The Higher Education curriculum is implemented through curricular, co-curricular and extracurricular activities.

The vision, mission, competency standard, and basic competency of MPK are to emphasize strengthening the personality of students as fully Indonesian people, who are 
consistently able to realize the basic values of religion and culture. The basic competence of Religious Education is to be a professional scientist, have faith and be devoted to God Almighty, have good morals, have a work ethic, have a mature personality, uphold the values of humanity and life. This means that the focus on internalizing values and theological differences and differences in schools on fiqihiyah issues does not become the main material in the teaching of PAI at PTU. The substance of PAI in the Personality Development Course (SK.No.43 Dikti, 2006) includes a) God Almighty and Godhead. - Faith and devotion - Divine philosophy (Theology). b). Human - Human nature - Human dignity - Human responsibility c). Law - Growing awareness to obey God's law - The prophetic function of religion in law d). Moral - Religion as a source of morality - Noble character in life e). Science, Technology and Art - faith, science and technology and charity as a whole. - Obligation to demand and practice knowledge. - Responsibilities of scientists and artists f). Harmony among religions - Religion is God's grace to all - Togetherness in religious plurality. g). Society - Civilized and prosperous society - The role of religious communities in realizing a civilized and prosperous society - Human Rights (HAM) and democracy. h). Culture - Academic culture - Work ethic, open and fair attitude i). Politics - The contribution of religion in political life - The role of religion in realizing the unity and integrity of the nation. The burden of group studies is 3 credits each (semester credit units) for courses in Religious Education, Citizenship Education, and Indonesian Language. This means that PAI at PTU is allocated as many as 3 SKS.

In practice, the competencies to be achieved through religious education are difficult to realize. There are several things that have caused the achievement of these competencies, including; (a) the number of credits for religious subjects is very limited, although some add 2 credits to become 4 credits (b) the dominant cognitive learning domain (c) the PAI teaching model is more likely to be dogmatize, uncritical, more doctrinal monologue, (c) inadequate PAI teaching material, (d) and inadequate lecturers, and (e) the career path of a religious lecturer at PTU that is different from the careers of other science lecturers [8].

In terms of methodology, PAI learning has not yet introduced many aspects of the rationality of religious teachings. PAI is impressed by the repetition of previous material so that PAI material is not accepted as something alive and responsive to the needs of students. Also, inadequate competence of teaching staff also becomes an obstacle and of course also in the use of PAI learning methods still using traditional, normative, historical and contextual learning. Several studies have found many PAI lecturers who are less able to elaborate and dialogue about PAI material with a socio-cultural context. The learning approach used is more pedagogical (the art or knowledge of guiding or teaching children) not yet on the practice of the learning process aimed at adults, which should be pedagogical. Because the teaching of PAI has not been able to meet the expectations of stakeholders, both PTU itself and the community in general, then led to a diversity of comments both from the leadership of PTU and among students which then resulted in the weakening of the PAI course position at PTU. When the diversity of comments and opinions is increasingly grouped, various steps emerge to look for other alternatives outside of intra-campus activities [6].

That is why, many students who are not satisfied with learning PAI on campus, deepen their religious insight through small halaqah, student religious organizations and other religious studies on their initiative. These Islamic study groups are more "sexy" and offer many colors and approaches in the understanding of Islamic religion, ranging from the textual normative nature to the contextual liberal. The different approaches are also the reasons students look for alternative PAI outside of PAI learning that is scheduled on campus. 
Based on the background above, this article writes the research results of the implementation of PAI Learning, especially at the Tanjung Pura University in Pontianak, West Kalimantan, which has several characteristics that are different from PTU in general.

The formulation of the problem proposed is how the implementation of PAI learning policies, How is the recruitment of PAI lecturers, how are the characteristics of PAI lecturers, How is the Learning model, and how is learning achievement at Tanjungpura University in West Kalimantan.

The results of this study are expected to be useful as input for the Ministry of Religion, particularly for the Directorate of Islamic Higher Education in the context of policymaking related to efforts to establish policies to improve the quality of PAI learning at PTU.

Adult Learning

The pattern of the teaching of religious education in tertiary institutions is different from the pattern of the teaching of religious education at primary and secondary levels. Students as adults are people who already have a lot of experience, knowledge, skills, and ability to overcome life's problems independently. Adults continue to try to improve their life experiences to be more mature in doing something to improve the quality of their lives. Adults are no longer the object of socialization that is formed and influenced by the authorities above themselves, but in an educational perspective, adults are more directed towards achieving their identity and identity stabilization to become themselves. Thus the participation of adults in learning has a positive impact on making changes to a better life. Thus the adult learning theory developed by Knowles, namely Andragogy, is the primary choice in adult learning.

Andragogy comes from the ancient Greek: "aner", with the root word and, which means adult, and agogos which means to guide or foster. Another term that is often used as a comparison is "pedagogy", which is drawn from the word "paid" meaning child and "agogos" meaning to guide or lead. Thus literally "pedagogy" means the art or knowledge of guiding or leading or teaching children. Because the notion of pedagogy is the art or knowledge of guiding or teaching children, when using the term pedagogy for educational activities for adults is inaccurate, because it contains conflicting meanings. Many practices of learning processes aimed at adults, which are supposed to be andragogical, are done in a pedagogical manner. In this case, the principles and assumptions that apply to children's education are considered applicable to adult training activities.

Thus, if the understanding is drawn in line with pedagogy, then andragogy can be interpreted as the science and art of teaching adults. But because adults as individuals who are already independent and able to direct themselves, then in andragogy the most important thing in the process of learning interaction is an independent learning activity that relies on the citizens of learning itself and is not an activity of a teacher teaching something (LearnerCentered Training / Teaching).

\section{Research methodology}

This research approach is qualitative. The main instrument in collecting case study data with this qualitative approach is the researchers themselves. Researchers become planners, implementing data collection, analysis, data interpreters and in the end he becomes a reporter of the results of his research [2]. The study was conducted at Tanjungpura University in West Kalimantan, because this university is a public university which has not been studied by the PAI learning organization model, so this type of research is explorative research. The informants of this study were the Vice-Chancellor 1 for Academic Affairs, the Coordinator of 
PAI lecturers, PAI Lecturers, SME activists in the religious field and non-religious activist students.

Data collection techniques are done by interview, observation and document review. Indepth interview technique in which the researcher acts as an instrument of data collection, the position of the researcher becomes a key instrument [3]. According to Guba and Lincoln, as data collection instruments researchers must be responsive, able to adjust, emphasize wholeness, base themselves on knowledge, respond to data as soon as possible, and use the time to classify and summarize data and take advantage of opportunities to look for unusual or idiosyncratic responses. That is why mastery of all concepts related to the scope of research (with the help of data collection matrices) is a prerequisite for researchers.

The next technique is observation, which is to see the pattern of student activities inside and outside the lecture hall (students' daily activities with a focus on religious activities on campus). Observations were made on the implementation of religious education learning, the behavior patterns of students in the PT environment which were focused on daily religious activities. Examine SAP documents, teaching materials and other references used. And document review is carried out to collect and analyze official documents related to the implementation of PAI learning.

Qualitative data analysis begins by describing, categorizing, then interpreting data and information on the organization of religious education at PTU. The description is based on the phenomenon found after data has been collected from various sources. By the types of data collected, this research uses descriptive qualitative data analysis techniques.

\section{Research results and analysis}

\subsection{PAI learning policy}

Religious education in higher education is a continuation of religious education carried out at the previous level of education. Namely starting from kindergarten level continued to elementary, then to junior high then to high school. From high school continued to college. The Dynamics of Religious Education in General Higher Education has been engraved in the history of education in the country since the beginning of the presence of universities in this country. Starting as a course that is considered not necessary to attend until its existence is 'presented' as a compulsory subject.

The implementation of Islamic Education at the University of Tanjungpura has gained a solid foundation since the issuance of MPRS Decree Number II of 1960 and the Higher Education Law No. 22 of 1961, which obliged the teaching of religious courses in state universities.

From the above quotation, it is clear that the position of Islamic religious education in general tertiary institutions has undergone significant restructuring. Its existence is increasingly recognized and needed in developing the potential of young generation resources (students) in the future. This condition is certainly inseparable from the policymakers in parliament whose post-reform efforts have increasingly seen 'smart' efforts, even though there are policies in other segments that are disappointing.

The implementation of PAI learning in public tertiary institutions, especially at Tanjungpura University in West Kalimantan, is in a fairly good category. This is known from the increase or achievement of students academically (GPA), but it is still theoretical and has not been able to change the overall academic behavior of students. Factors that influence PAI learning at PTU are: a small allocation of learning time, PAI learning is more oriented to non- 
practical material and a lack of increased insight into PAI lecturers in the form of seminars, workshops, and training [4]

Islamic Religious Education (PAI) at Tanjungpura University is included in the Personality Development (MPK) course because the main purpose of the PAI course here is to develop the personality of students as a whole with the hope that students will become faithful scientists and fear Allah SWT. , and able to devote his knowledge to the welfare of humanity. Therefore, PAI courses at Tanjungpura University are grouped in personality development courses (MPK).

Besides that, according to the Decree of the Director-General of Higher Education Ministry of the National Education Republic of Indonesia Number: 43 / DIKTI / Kep / 2006 Concerning the Implementation of Personality Development Courses in Higher Education, that Religious Education is one of the subjects of personality development (MPK). The vision of this course is a source of values and guidelines for the implementation of study programs in delivering students to develop their personality as fully Indonesian people. While its mission is to help students to be able to realize the basic values of religion in applying technological science and art which they master with a sense of humanitarian responsibility (articles $1 \& 2$ ).

Judging from the vision and mission of PAI at PTU, ideally, PAI at PTU is developed towards the organism paradigm, which makes PAI as a source of values and guidelines for organizing study programs and helping students (prospective graduates) to be able to realize the basic values of religion in applying science technology and art. The direction of Islamic Religious Education policy at Tanjungpura University began to change since the integration of the Religious-Based Character Education Program into Tanjungpura University's Religious Education Subjects through Chancellor Decree number 1540 / UN22 / DT / 2012 dated 20 December 2012 (Pendikar weighs 1 SKS out of a total of 3 SKS for Religious Education). In the early years of this integration, decree had not been maximally applied because both students and lecturers were still using the old paradigm. Along with the restructuring of the management of the General Course, starting from the new academic year 2015/2016 the integration of character education programs into religious subjects is even more massive (letter of rector no.1540 / UN22 / DT / 2012) [8].

The Character Education Program at Tanjungpura University is based on the religion of each student. This program must be attended by new students and old students who repeat courses in Religious Education. Implementation of this program in semester one with effective time spent for 4 months (September - December). There are 6 religious-based Character Education programs at Tanjungpura University, namely Islamic Education, Catholic Education, Christian Education, Buddhist Education, Hindu Education, and Confucian Education.

In general, the character education program is held every week on Friday at $13.00-15.00$ based on the Rector's circular because this program involves all new students around 6000 students from 9 different faculties in one small group (Circular of Rector 6086 / UN22? DT / 21015). The program equates new students between faculties in small groups called families. Each family consists of 11-12 new students who are guided by a senior who is appointed as the head of the family (latent danger of brawls between faculties). Participants in the Character Education Program are required to carry out worship by their respective religions and are required to read their respective scriptures until khatam (completed). Every family group every week periodically until one semester is obliged to send weekly activity reports containing attendance, silaturrahim assignments among family members, meeting resumes and daily worship activities through an archive group on Facebook so that they can be read by 
anyone who accesses them. For more details, you can access the Tanjungpura University Character Education Program website at www.pendikar.untan.ac.id.

The Manager of General Elementary Courses (MKDU) of Tanjungpura University was given the responsibility of being a Technical Implementation Unit of the organizers of learning courses on Religious Education, Citizenship and Indonesian Language Education Pancasila at Tanjungpura University (DIKTI no 43 / DIKTI / Kep / 2006). MKDU in collaboration with PAI lecturers formulated and agreed on the composition of the final grades as mandated by the Rector's Decree number 1540 / UN22 / DT / 2012 by including 30\% PAI assessments from the Character Education Program.

\section{Analysis}

The new policy by bringing up the Character Education Program based on Religion made Islamic Religious Education Courses at Tanjungpura University more enjoyable for students. Islamic Education at the University of Tanjungpura became not only at the level of theory in the classroom but also aspects of practice which included the practice of ukhuwwah Islamiyah, the practice of worshiping fardhu, tadabbur Al Qur'an to khatam. By requiring new students to perform Fardhu Prayer at the beginning of time for one semester can cause them to get accustomed in carrying out Fardhu Prayer at the beginning of time. By requiring students who participate in the Pendikar program to read the translation of the Holy Qur'an to khatam, it can increase insight as well as new students' confidence so that it motivates them to worship even better in the next semester.

The practice of ukhuwwah Islamiyah in character education programs is one solution to the frequent conflicts between faculties at Tanjungpura University. Grouping with small numbers is more effective than gathering new students in large groups. Large groups make students group according to their respective faculties so that the purpose of making them equal won't be achieved. Conversely, grouping on a small scale can increase the intensity of interaction between students of different faculties so that the goal of ukhuwwah Islamiyah can be achieved.

By requiring the practice of worship fardhu at the beginning of time for one semester can lead to the habit of carrying out worship without supervision again. Something that is used to being done is easier to do. In this character education program also requires students to memorize and practice prayers, Ridsdale, prostration and bargaining which are relatively long and their meanings. Often the command to pray in the Qur'an is represented by the command ruku and prostration which have meaning in prayer. The hadith of Prophet Muhammad SAW also advocated prolonging prostrations by making relatively long prayers because prayer is the weapon of the faithful.

By requiring students to read the translation of the Qur'an at least 7 (seven) pages per day, within one semester students can memorize the translation of the Qur'an. This is applied because it takes a long time to understand the language of the Qur'an while the time available to require students to attend PAI lectures is only one semester. This illustration is like a factory producing a sophisticated technology product where each product has a manual book that guides the use of that product. Likewise humans as creatures created by Allah SWT certainly also given a manual book in the form of the holy book of the Koran. So that students can easily learn life and life then they are required to read translations of the Koran.

The support of the management of General Basic Courses (MKDU) also provides convenience in integrating the Character Education Program into Islamic Religious Education. 
MKDU Manager facilitates the regulation of the Character Education Program in Islamic Education lectures.

With the help of the online re-registration system of new students who were accepted at Tanjungpura University, the information on the Character Education Program that was integrated into the Religious Education Course was more quickly known by prospective students and parents/guardians of students. The willingness form to join this program automatically comes out after online registration and must be signed by students and parents/guardians. This is as information and socialization so students and parents/guardians can prepare themselves.

\subsection{Recruitment of PAI lecturers}

Recruitment of PAI Lecturers on this campus follows the recruitment of civil servants by the central government by the formation of recruitment at the University of Tanjungpura. Recruitment of PAI Lecturers on this campus was announced through electronic media such as websites and other media such as newspapers and notice boards. However, according to the secretary of the management of the General Basic Course (MKDU) who is also the coordinator of the PAI lecturer (Riadi Budiman, ST., MT) explains that the PAI lecturer recruitment mechanism at this tertiary institution has not been done for a long time. This has caused the ratio of PAI lecturers to Islamic Masters qualifications to continue to decline along with the increase in students and the opening of new study programs.

In the beginning, Tanjungpura University accepted dozens of PAI lecturers with religious S1 qualifications, only one person who continued the field of religion until S3 then became Deputy Regent in Sambas Regency and 3 people took Masters Degree in Religion then S3 was not Religion, one person took Masters, not Religion while another moved to School Pontianak State Islamic High Religion because there is no major of religion at Tanjungpura University.

The main requirements in the recruitment of PAI lecturers on this campus are Minimum Masters level and competence, good personality, professional, social, religious. Matters considered in the recruitment of PAI teaching staff at Tanjungpura University are: 1) The transparency of the recruitment of PAI lecturers is by the formation of PNS admissions. 2) The main requirements in the recruitment of PAI lecturers are by the requirements of PNS lecturers. 3) The parties involved in the recruitment of PAI lecturers are by the PNS admissions rules. 4. Decision-making mechanism in the determination of the appointment of PAI lecturers based on the rules in force in the Ministry of Research, Technology and Higher Education.

To cover the shortage of PAI lecturers at Tanjungpura University, the university and faculty leaders agreed that starting the 2015/2016 academic year semester PAI appointed PAI lecturers from each faculty lecturer who had an example in carrying out fard prayer in congregation at a mosque or mosque. The appointed lecturer was then included in the PAI lecturer training held by Tanjungpura University in collaboration with the Indonesian Ulema Council of West Kalimantan, the Syarif State Islamic Institute of Pontianak and the West Indonesian Dai Association of West Kalimantan (Rector's Circular Letter no. 6086 / UN22 / DT / 2015) [10].

\section{Analysis}

The diverse educational background of S2 / S3 lecturers, both with a religious certificate and general certificate, shows that they have teaching qualifications in undergraduate strata, 
and even all have certification as lecturers. With the busyness of both lectures, research and community service, the interaction of lecturers with students outside the classroom and the community outside the campus are very less. This also influences the lecturers' opinions and attitudes towards new events or things that occur around them. This busy activity of PAI lecturers also results in their inactivity in existing social organizations both formal and informal.

With a very large ratio of PAI lecturers and students, attention, concentration, and guidance to students is ineffective and tends to only fulfill tasks and obligations. This, of course, causes the learning objectives of PAI to be not maximally achieved.

Recruitment of lecturers supporting Islamic Religious Education Courses from permanent lecturers in each study program has some good impacts for the students as well as the lecturers concerned. For students, because PAI lecturers are also permanent lecturers of study programs, which always meet with an excellent role model. Students feel that PAI is not just a theory in the classroom, but also the practice of religious worship by PAI lecturers who always invite them to worship, including the practice of everyday noble morals. For the lecturers concerned, they are motivated to further deepen religious knowledge as well as the cause of the decline of guidance from Allah SWT because they always teach religious knowledge through PAI lectures. The exemplary of PAI lecturers and PAI students contributed to the good impact of the entire academic community in the study program.

Recruitment of lecturers supporting Islamic Religious Education Courses from permanent lecturers of study programs also makes it easier in the PAI lecture learning system because permanent lecturers of study programs have competency as lecturers and have lecturer certification in teaching a course.

The heterogeneous culture of West Kalimantan society also contributes to the impact of tolerance and religious harmony for PAI lecturers. Religious tolerance and harmony are the main principles in national life in the Republic of Indonesia (NKRI). In socio-economic terms, lecturers who are capable of adequate PAI courses have a good impact on PAI lectures. This causes the absence of PAI lecturers who sell diktat (grades) to their students so that the assessment is more transparent and objective.

With the busyness of each PAI lecturer through lectures, research and community service, they rarely interact with existing religious ideas. PAI lecturers are not only preoccupied with their respective affairs because of the demands of the lecturer workload performance that must be met, as well as their desire to increase family income.

\subsection{Characteristics of PAI lecturers in general higher education}

In general, the backgrounds of the lecturers who taught PAI courses at Tanjungpura University were from S-2 graduates and some had S3 degrees with various disciplines. The religious understanding of Islamic Religious Education lecturers, in general, is good and does not have an extreme understanding. The lecturers are not involved in social organization activities due to the tight schedule of lectures and research so they do not have time to do activities outside the campus.

The lecturers who had a religious certificate were first recruited and placed in the Department of Sociology at the Faculty of Social and Political Sciences because Tanjungpura University did not have a major in Religion. This caused some of them to move to religious colleges in the city of Pontianak and some to continue their masters and doctoral degrees in other fields so that the remaining 5 (five) lecturers of Religion remained to teach PAI. With 
this limitation, some PAI lectures are sometimes not attended by lecturers or their classes are combined to form large classes [4].

To overcome the shortage of lecturers supporting this PAI course, the leaders of the University and the Faculty recruit the lecturers of each study program to teach religious subjects as explained previously. The characteristics of study program lecturers recruited to become PAI lecturers are more or less the same as those of religious lecturers who hold a religious degree.

Armed with experience in teaching in the classroom and getting training to improve competence as a lecturer, all PAI lecturers with a religious degree or not, can deliver material in class.

The heterogeneous culture of West Kalimantan society also influences Islamic Education lecturers and their families. They live next door to various ethnic, ethnic and religious groups. All PAI lecturers are Malay and have education in West Kalimantan and Java, only one of them studied in Malaysia taking a doctorate in sociology.

The socio-economic level of PAI lecturers today is better in line with the government policy of providing lecturer certification allowance and the economic average of the lecturer family is supported by family partners (husband or wife) who also work and some even have side businesses (restaurants, rented houses and stalls small).

The lecturers can concentrate on giving PAI lecture material and they are not influenced by existing religious ideologies because the lecturer is busy with the schedule of lectures and research so there is no time to interact outside the classroom with students.

\section{Analysis}

The diverse educational background of S2 / S3 lecturers, both with a religious certificate and general certificate, shows that they have teaching qualifications in undergraduate strata, and even all have certification as lecturers. With the busyness of both lectures, research and community service, the interaction of lecturers with students outside the classroom and the community outside the campus are very less. This also influences the lecturers' opinions and attitudes towards new events or things that occur around them. This busy activity of PAI lecturers also results in their inactivity in existing social organizations both formal and informal.

With a very large ratio of PAI lecturers and students, attention, concentration, and guidance to students is ineffective and tends to only fulfill tasks and obligations. This, of course, causes the learning objectives of PAI to be not maximally achieved.

Recruitment of lecturers supporting Islamic Religious Education Courses from permanent lecturers in each study program has some good impacts for the students as well as the lecturers concerned. For students, because PAI lecturers are also permanent lecturers of study programs, which always meet with an excellent role model. Students feel that PAI is not just a theory in the classroom, but also the practice of religious worship by PAI lecturers who always invite them to worship, including the practice of everyday noble morals. For the lecturers concerned, they are motivated to further deepen religious knowledge as well as the cause of the decline of guidance from Allah SWT because they always teach religious knowledge through PAI lectures. The exemplary of PAI lecturers and PAI students contributed to the good impact of the entire academic community in the study program.

Recruitment of lecturers supporting Islamic Religious Education Courses from permanent lecturers of study programs also makes it easier in the PAI lecture learning system because 
permanent lecturers of study programs have competency as lecturers and have lecturer certification in teaching a course.

The heterogeneous culture of West Kalimantan society also contributes to the impact of tolerance and religious harmony for PAI lecturers. Religious tolerance and harmony are the main principles in national life in the Republic of Indonesia (NKRI).

In socio-economic terms, lecturers who are capable of adequate PAI courses have a good impact on PAI lectures. This causes the absence of PAI lecturers who sell diktat (grades) to their students so that the assessment is more transparent and objective.

With the busyness of each PAI lecturer through lectures, research and community service, they rarely interact with existing religious ideas. PAI lecturers are not only preoccupied with their respective affairs because of the demands of the lecturer workload performance that must be met, as well as their desire to increase family income.

\subsection{PAI lecture model}

In general, the model of Islamic Religious Education lectures at Tanjungpura University has shifted to the teaching system of andragogy. This can be seen from the many tasks that must be done by students as well as being presented in front of the class. More lecturers become facilitators or directors. Nevertheless, there are still lecturers who use the old style of teaching, namely the pedagogical model because this lecturer lectures more often beginning to the end of the lecture so that students look passive.

With the recruitment of Islamic Religious Education lecturers from each study program who has a scientific background that is suitable for students, making the class active and fun because every discussion of lecture material is directly linked to the field of study the students pursue. With this program, it is expected that students' interest and motivation in studying Dinul Islam will improve which can eventually produce scientists as well as religious.

It is inseparable from the revolving recruitment program of Islamic Religious Education lecturers originating from each study program, making the ratio of student lecturers in the class smaller, an average of 30 students per class. This small class makes it easy to apply andragogy teaching models.

From the background of the lecturers at Tanjungpura University who have participated in training in teaching capacity building and have had a lecturer certificate, they show that they have known and studied the theory of teaching models, both pedagogy and andragogy. This knowledge makes it easier for PAI lecturers to apply various methods of teaching andragogy.

By incorporating the components of the Islamic Religion-based Character Education Program into the Islamic Religious Education course, it has a positive influence on the learning of this course because this program is a practice of the PAI theory learned so far in the classroom.

\subsection{PAI lecture achievement}

In general, the development of the learning process of Islamic Religious Education at Tanjungpura University is held interactively, inspiratively, fun, challenging and motivates students to participate actively in lectures. This is inseparable from the background of lecturers who already have lecturer certifications and take part in teaching training in tertiary institutions. Each lecturer has applied the adult learning method (andragogy) so that students are motivated to learn independently, work on assignments, presentations, and discussions. Another thing is starting to build the atmosphere of the religious atmosphere on campus 
because many study program lecturers are involved in caring for Islamic Religious Education courses.

With the integration of the character-based religion education program into religious education courses, it will accelerate students' understanding, faith and piety to God Almighty, as well as having good morals and being able to maintain peace and harmony between and among religious communities. This program is also able to reduce hostility conflicts between faculties as evidenced by the disappearance of brawl events involving students between faculties because this program equates students of different faculties in one small family for one semester.

COVER

The implementation of PAI learning at Tanjungpura University, before 2012 was in a quite good category. This is known from the increase or achievement of students academically (GPA), but it is still theoretical and has not been able to change the overall academic behavior of students. Factors that influence PAI learning at PTU are: a small allocation of learning time, PAI learning is more oriented towards non-practical material and a lack of increased insight into PAI lecturers in the form of seminars, workshops, and training.

Organizing Islamic Education at Tanjungpura University is the core course for all study programs both S1 and D3 with a weight of 3 SKS. Since 2012 backward, these 3 SKAI weighted PAI have been allocated 1 SKS for the Character-Based Character Education Program, so the number of face-to-face lectures in Islamic Education was reduced to 2 SKS

Islamic Character-Based Education Program emphasizes ukhuwwah Islamiyah among faculties, applies and memorizes i'idal prayers and prolonged iundidal prostrations and their meanings, implements fardhu prayer early in time (congregation for men) and reads a translation of the Qur'an to khatam.

Starting in 2014, massive recruitment of PAI lecturers was carried out from each study program at Tanjungpura University, which already had a capital base in the form of observance of the Fardhu Prayer early on campus. The massive recruitment of PAI lecturers is expected to give birth to the competence of being a scientist and professional who has faith and is devoted to God Almighty, has good morals, and has a work ethic that can be achieved.

All Islamic Education lecturers, both old and recruits at Tanjungpura University have lecturer certifications and have received teaching a training in tertiary institutions making it easier for them to apply andragogy learning models to their students.

Based on the conclusions in this study, some suggestions can be made, namely, first, the learning process of Islamic Religious Education at Tanjungpura University needs to be supported by lecture facilities and infrastructure as well as institutional policies that consistently improve the quality of lectures as well as the religious atmosphere on campus. Second, two breakthroughs at the University of Tanjungpura, namely the religious-based Character Education Program and the PAI lecturer recruitment program from lecturers of each Faculty's study program, should be emulated and implemented in other public universities.

\subsection{Resource identification}

From this study, several respondents were identified as resource persons to obtain data, namely:

1. Ir. Abubakar Alwi, MT, Ph.D , telp.181257900232, Pembantu Rektor I Universitas Tanjungpura

2. Riadi Budiman, ST., MT Koordinator PAI Universitas Tanjungpura Pontianak Kalbar, telp 085752929507 
3. Dra. Syarmiati, M.Si, Dosen PAI Universitas Tanjungpura, Telp 08125748535

4. Dr. Bahran Suni, M.Ag, Dosen PAI Universitas Tanjungpura, telp 0812575358

5. Dr. Hj. Hasanah, M.Ag, Dosen PAI Universitas Tanjungpura, Telp 081345971755

6. Reza Wirawan, BKMI (Badan Kerohanian Mahasiswa Islam), Mahasiswa aktif organisasi Universitas Tanjungpura, TELP. 081352207234

7. Prima Yuliantoro, Badan Eksekutif Mahasiswa Universitas Tanjungpura, Telp 0899 2541,811

8. Eka Fitraningsih, BKMI (Badan Kerohanian Mahasiswa Islam), Mahasiswa aktif organisasi Universitas Tanjungpura, TELP. 08964112899

9. Lely Harfina, Mahasiswa Universitas Tanjungpura, telp. 08990542154

10. Rino, IKIP PGRI Pontianak, Telp 089682377845

11. Arie Firmansyah, mahasiswa Fakultas Hukum Universitas Tanjungpura, Telp 0852 45677695

12. Asih Wiranti, Mahasiswa Universitas Tanjungpura, Telp. 08963691437

13. Gabrella Edena Stokhorst, Mahasiswa Universitan Tanjungpura, Telp. 085258699888

14. Umi Yuriamita, Mahasiswa Universitan Tanjungpura, Telp. 082154162101

Eka Bhekti Prima Utami, Mahasiswa Universitan Tanjungpura, Telp 089661338689

\section{References}

[1] Attachment to Minister of Education Regulation Number 41, (2007). November 23, 2007, concerning Poses Standards for Primary and Secondary Education Units

[2] Moleong, Lexy. 1998. Metode Penelitian Kualitatif. Edisi Revisi. Bandung : PT. Remaja Rosdakarya.

[3] Sugiyono. 2008. Understanding Qualitative Research, Bandung: Alfabeta.

[4] Ir. Abubakar Alwi, MT, Ph.D , telp.181257900232, Pembantu Rektor I Universitas Tanjungpura

[5] Riadi Budiman, ST., MT Koordinator PAI Universitas Tanjungpura Pontianak Kalbar, telp 085752929507

[6] Imran Siregar, Islamic Teaching Model at the University of North Sumatra Medan, "Al-QOLAM" Journal of Religion and Socio-Cultural Research, Volume 20, Number 1 June 2014.

[7] PP No 55 of 2007 concerning Religious and Religious Education

[8] Research Team of R \& D Agency and Training, Evaluation of Islamic Education Implementation in General Higher Education, Research and Development Agency of the Ministry of Religion, Republic of Indonesia, Jakarta. 2003.

[9] Decree of the Chancellor of Tanjungpura University number 1540 / UN22 / DT / 2012

[10] Circular of the Chancellor of Tanjungpura University no 6086 / UN22 / DT / 2015 